\title{
ANTIMICROBIAL ACTIVITY OF EXPERIMENTAL ENDODONTIC SEALER BASED ON BIOCERAMIC NANOMATERIALS
}

\section{LUCIA IACOBINA TIMIS ${ }^{a *}$, MARIA GOREA ${ }^{b *}$, CARMEN COSTACHEc, IOANA ALINA COLOSI ${ }^{c}$, PAVEL SCHIOPU ${ }^{c}$, PAUL-STEFAN PANAITESCU ${ }^{c}$, ADA DELEAN ${ }^{a}$, DINU IULIU DUMITRASCU ${ }^{d}$, RADU SEPTIMIU CÂMPIAN ${ }^{\mathrm{e}}$}

\begin{abstract}
The aim of this work was to evaluate the antimicrobial effectiveness of a bioceramic experimental endodontic sealer (EES), alongside with its components. As a novelty, magnesium silicate was incorporated into the experimental material, in order to improve the mechanical performance of the product. The main oxide components, tricalcium silicate $\left(\mathrm{Ca}_{3} \mathrm{SiO}_{5}\right)$ and magnesium silicate $\left(\mathrm{Mg}_{2} \mathrm{SiO}_{4}\right)$ were synthesized in nanoparticles from specific precursors by a sol-gel method. To compare the efficiency of the new developed product, commercially available materials, with similar chemical composition, used in everyday practice, were also tested: BC Sealer, MTA Bioceramic Root Canal Sealer, and MTA Fillapex. The method employed for the present study was the agar well diffusion test (ADT). The selected microbial strains were Enterococcus faecalis and Candida albicans, frequently associated with persistent infection and recurrent infections of the endodontic space, as well as periapical pathologies refractory to endodontic treatment. Measurements of the inhibition areas were performed at 24-hour intervals for 7 consecutive days. Tricalcium silicate and all tested endodontic sealers revealed antimicrobial effectiveness against Candida albicans at 24 hours after placement, with a prolonged activity, for up to 7 days. The study revealed no antibacterial effect against Enterococcus faecalis at 24 hours nor in the following 7 days, for any of the tested samples.
\end{abstract}

Keywords: antimicrobial activity, bioceramic, endodontic sealer, tricalcium silicate

a Iuliu Hațieganu University of Medicine and Pharmacy, Faculty of Dentistry, Department of Odontology, 33 Calea Motilor str., RO-400001 Cluj-Napoca, Romania.

b Babeş-Bolyai University, Faculty of Chemistry and Chemical Engineering, 11 Arany Janos str., RO-400028, Cluj-Napoca, Romania.

c Iuliu Hațieganu University of Medicine and Pharmacy, Faculty of Medicine, Department of Molecular Sciences, Division of Microbiology, 6 Louis Pasteur str., RO-400349, ClujNapoca, Romania.

d Iuliu Hatieganu University of Medicine and Pharmacy, Faculty of Medicine, Department of Anatomy and Embryology, 3-5 Clinicilor str., RO-400006 Cluj-Napoca, Romania.

e Iuliu Hațieganu University of Medicine and Pharmacy, Faculty of Dentistry, Department of Oral Rehabilitation, 15 Victor Babes str., RO-400012, Cluj-Napoca, Romania.

*Corresponding author: maria.gorea@ubbcluj.ro, Timis.Lucia@umfcluj.ro 


\section{INTRODUCTION}

The success of the endodontic treatment is given by the absence of acute or chronic apical periodontitis in endodontically treated teeth. This goal can be achieved by eliminating microorganisms and their by-products from the root canal and avoiding further recontamination [1-3].

Endodontic obturating materials that exhibit antimicrobial properties may be helpful in reducing the contamination of the endodontic space, thus increasing the success rate of the treatment.

Currently, a great number of endodontic sealers are available for clinical use. According to their composition and based on its main component, they belong to one of the following groups: zinc oxide eugenol, calcium hydroxide, epoxy resin, silicone, glass ionomer, methacrylate resin, calcium phosphate or calcium silicate based materials.

The chemical composition of endodontic sealers can influence the products' antimicrobial properties $[4,5]$. Most endodontic sealers that present significant antimicrobial properties also exhibit an irritating or toxic effect upon the periapical tissues and oral mucosa, especially those containing epoxy resins, methacrylate resins, formaldehyde, or eugenol [1]. Consequently, the aim to produce the least possible harm to the surrounding tissues is often hard to achieve, as root canal obturating materials are placed in proximity to the periapical area.

The development of bioceramic nanomaterials based on calcium silicates and calcium phosphates marked a new stage both in medicine and dentistry. In addition to their superior physical properties, they are biocompatible, being very well tolerated by the periapical tissues, and bioactive, inducing bone healing and regeneration $[6,7]$.

Bioceramic endodontic sealers have been developed as an alternative to conventional materials used for root canal obturation since 2007. Their main constituents, calcium silicates, calcium phosphates, or both, are combined with one or more of the following components: calcium hydroxide, zirconium oxide, bismuth oxide, calcium sulphate, tricalcium aluminate, resins, calcium salicylate, mineral trioxide aggregate $[8,9]$.

TotalFill BC sealer (FKG, Switzerland) is a premixed ready to use hydrophilic sealer based solely on inorganic compounds. It presents an increased biocompatibility due to its composition, and a success rate of $90.9 \%$ in nonsurgical endodontic treatments [10]. It has an alkaline $\mathrm{pH}$, due to $\mathrm{OH}^{-}$ion release, and superior bioactivity compared to other materials, including the ones in its class [11]. 
MTA Bioceramic Sealer (Henry-Schein, USA) and MTA-Fillapex (Angelus, Brazil) are both formulated as two paste systems, designed to be mixed prior to their placement inside the root canal. They have similar composition, consisting of mineral trioxide aggregate as a source for calcium silicates and $\mathrm{R}_{2} \mathrm{O}_{3}$ (mainly $\mathrm{Bi}^{3+}$ ) associated with organic resins: salicylate resin and diluting or base resins. Their bioactivity and biocompatibility are proven to be inferior compared to resin-free bioceramic materials, but still, superior to other classes $[12,13]$.

Various studies were performed upon different types of pathogens, in order to assess the antimicrobial effect of commercial endodontic sealers. Agar diffusion test (ADT) was the most used. The results for bioceramic sealers are subject to controversies. Some studies revealed their long-term antimicrobial properties [14], while others only revealed a short-term effect [15], or even none [4].

Enterococcus faecalis, a facultative anaerobic bacterium, holds the ability to penetrate dentinal tubules, form biofilms, survive nutritional deprivation and resist antimicrobial sealers, thus generating persistent periapical infections $[16,17]$.

Candida albicans, an opportunistic yeast, manifests high resistance in the oral cavity and has an affinity to dentin, penetrating dentinal tubules. It can survive in hostile environments and is involved as causal agent of endodontic treatment failures $[18,19]$.

The coexistence of $E$. faecalis and $C$. albicans has been observed, the two microorganisms being co-isolated in $10 \%$ of the periapical and root canal infections and in $40 \%$ of the oral lesions [20]. Fungal-bacterial interactions are deemed problematic because the presence of $C$. albicans was proven to increase the metabolic activity of the biofilm, indicating its fast growing and colonisation, with an increased resistance to antimicrobial treatment [21].

The aim of this in vitro study was to evaluate the antimicrobial properties of an experimental bioceramic sealer (EES) as well as the individual properties of its main components: tricalcium silicate $\left(\mathrm{Ca}_{3} \mathrm{SiO}_{5}\right)$, zirconium dioxide $\left(\mathrm{ZrO}_{2}\right)$, magnesium silicate $\left(\mathrm{Mg}_{2} \mathrm{SiO}_{4}\right)$ and zinc chloride $\left(\mathrm{ZnCl}_{2}\right)$. Similar commercially available bioceramic sealers were tested for comparison: BC Sealer, MTA Bioceramic Root Canal Sealer, and MTA Fillapex.

The study was performed using the agar diffusion test (ADT) on strains of pathogens incriminated in inducing periradicular infections resistant to treatment: Enterococcus faecalis and Candida albicans. The properties were evaluated on a 7-day period starting at 24 hours after placement. 
L. I. TIMIS, M. GOREA, C. COSTACHE, I. A. COLOSI, P. ȘCHIOPU, P. Ș. PANAITESCU,

A. DELEAN, D. I. DUMITRASCU, R. S. CÂMPIAN

\section{RESULTS AND DISCUSSIONS}

All tested endodontic sealers' antimicrobial activity was assessed by measuring the diameters of the inhibition zones that could be observed around each well, at 24-hour intervals for 7 consecutive days.

Duplicate measures were averaged, and Friedman test was used to determine the significance of the difference between the tested materials. Post-hoc analysis was performed using Dunn pairwise comparisons with Bonferroni correction for multiple testing.

\section{Candida albicans}

All commercially available sealers, as well as tricalcium silicate and the experimental composition (EES) displayed consistent growth inhibition for $C$. albicans, as presented in Figure 1.
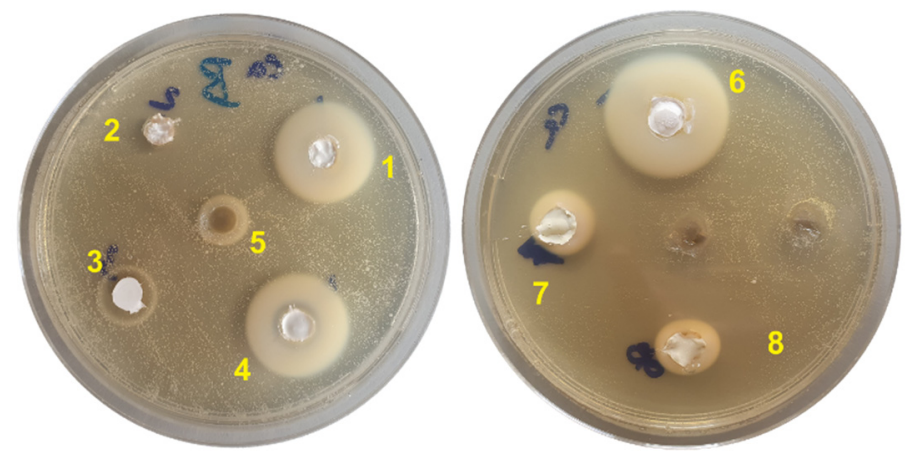

Figure 1. ADT of multiple sealers on Candida albicans inoculated plate:

1 - Tricalcium silicate $\left(\mathrm{Ca}_{3} \mathrm{SiO}_{5}\right), 2$ - Magnesium silicate $\left(\mathrm{Mg}_{2} \mathrm{SiO}_{4}\right), 3$ - Zirconium dioxide $\left(\mathrm{ZrO}_{2}\right), 4$ - Experimental sealer (EES), 5 - Zinc chloride $\left(\mathrm{ZnCl}_{2}\right)$,

6 - TotalFill BC Sealer, 7 - MTA Bioceramic Sealer, 8 - MTA-Fillapex.

Mean values of the diameters of the inhibition zones were calculated for each sample and presented in Table 1.

Friedman test showed significant differences between the medians of the measurements $\left(x^{2}=27.07, p<0.05\right)$, as presented in Figure 2 . 
ANTIMICROBIAL ACTIVITY OF EXPERIMENTAL ENDODONTIC SEALER BASED ON BIOCERAMIC NANOMATERIALS

Table 1. Average measurements of the zones of $C$. albicans diameters of inhibition zones $(\mathrm{mm})$.

\begin{tabular}{|c|c|c|c|c|c|c|c|c|}
\hline Sealer & $\begin{array}{c}\text { Day } \\
1\end{array}$ & $\begin{array}{c}\text { Day } \\
2\end{array}$ & $\begin{array}{c}\text { Day } \\
3\end{array}$ & $\begin{array}{c}\text { Day } \\
4\end{array}$ & $\begin{array}{c}\text { Day } \\
5\end{array}$ & $\begin{array}{c}\text { Day } \\
6\end{array}$ & $\begin{array}{c}\text { Day } \\
7\end{array}$ & Median \\
\hline $\begin{array}{c}\text { Tricalcium silicate } \\
\left(\mathrm{Ca}_{3} \mathrm{SiO}_{5}\right)\end{array}$ & 20.3 & 20.0 & 20.5 & 20.7 & 20.4 & 20.2 & 21.0 & 20.4 \\
\hline $\begin{array}{c}\text { Magnesium silicate } \\
\left(\mathrm{Mg}_{2} \mathrm{SiO}_{4}\right)\end{array}$ & 0.0 & 0.0 & 0.0 & 0.0 & 0.0 & 0.0 & 0.0 & 0.0 \\
\hline $\begin{array}{c}\text { Zirconium dioxide } \\
\left(\mathrm{ZrO}_{2}\right)\end{array}$ & 0.0 & 0.0 & 0.0 & 0.0 & 0.0 & 0.0 & 0.0 & 0.0 \\
\hline $\begin{array}{c}\text { Experimental sealer } \\
\left(\mathrm{Ca}_{3} \mathrm{SiO}_{5}, \mathrm{Mg}_{2} \mathrm{SiO}_{4}, \mathrm{ZrO}_{2},\right. \\
\mathrm{ZnCl})\end{array}$ & 20.0 & 20.0 & 20.0 & 20.3 & 20.3 & 20.1 & 21.2 & 20.1 \\
\hline $\begin{array}{c}\text { Zinc chloride } \\
\left(\mathrm{ZnCl}_{2}\right)\end{array}$ & 0.0 & 0.0 & 0.0 & 0.0 & 0.0 & 0.0 & 0.0 & 0.0 \\
\hline TotalFill BC Sealer & 26.0 & 24.0 & 24.0 & 24.5 & 24.9 & 25.1 & 25.5 & 24.9 \\
\hline MTA Bioceramic Sealer & 25.7 & 22.0 & 24.0 & 22.0 & 22.5 & 22.1 & 24.0 & 22.5 \\
\hline MTA-Fillapex & 25.0 & 21.5 & 22.0 & 20.8 & 21.2 & 21.1 & 23.3 & 21.5 \\
\hline
\end{tabular}

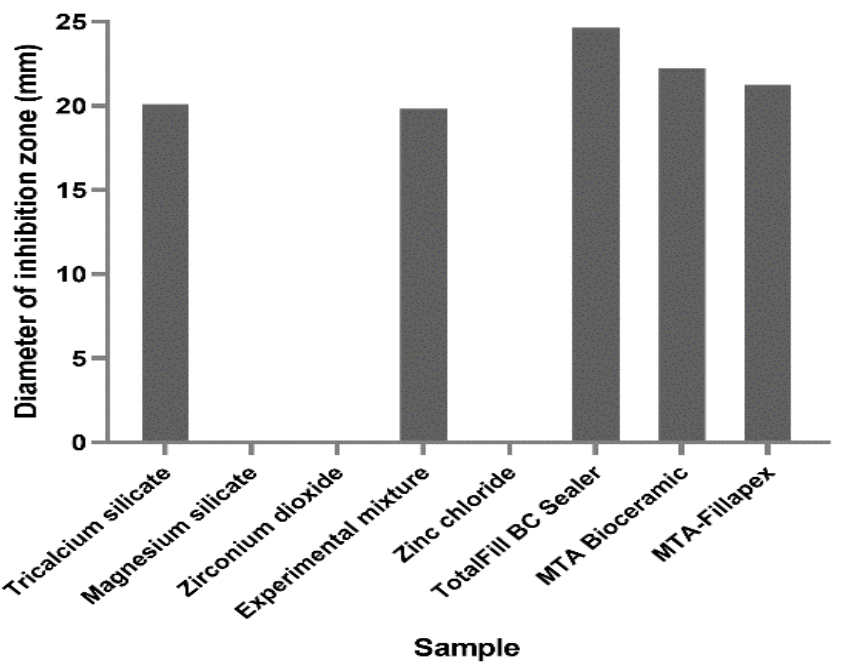

Figure 2. Medians of the measurements of $C$. albicans diameter of inhibition zone. 
Regarding the antifungal effect against $C$. albicans, tricalcium silicate showed no significant statistical difference from MTA-Fillapex $(p=1)$ and MTA Bioceramic Sealer $(p=0.068)$. The experimental sealer showed no statistically significant difference compared to MTA-Fillapex $(p=0.346)$. MTA Bioceramic Sealer performed better than the experimental sealer $(p<0.05)$. TotalFill BC Sealer performed better than both tricalcium silicate $(p<0.05)$ and the experimental sealer $(p<0.05)$. There was no statistical difference between tricalcium silicate and the experimental sealer's ability to inhibit the growth of C. albicans $(p=1)$, suggesting that Tricalcium silicate's inhibitory activity remains constant even when present as part of this composition. Zinc chloride $\mathrm{ZnCl}_{2}$ solution produced no inhibition zones. Further studies are needed to better understand Tricalcium silicate's inhibitory action upon $C$. albicans and how this effect is influenced by its concentration in the sealing material.

Fungi are common inhabitants of the gastrointestinal tract and the oral cavity in the human body. Therefore, they can be present in the microbiota of infected root canal. Candida albicans is the yeast most isolated from these infections [22,23]. It has an affinity to dentin, is able to penetrate dentinal tubules, and can adapt to different environments [24].

The pathogenicity of $C$. albicans is further increased by its ability to form biofilms, thus becoming 10-100 times more resistant to common medication than planktonic cells. Like $E$. faecalis, it is often responsible for persistent endodontic related infections that are reluctant to treatment [25].

There is a consensus in literature regarding the antifungal properties of bioceramic sealers. Tested bioceramic sealers exhibited antimicrobial effect against strains of Candida albicans on ADT. Authors have described them having moderate activity, but still not as significant as other classes, like epoxy resin materials [26], or zinc oxide eugenol materials [15], more pronounced that methacrylate-based materials [27].

The present study revealed antifungal activity against $C$. albicans for all commercial endodontic sealers along with calcium silicate and experimental sealer. The effect was present at 24 hours after placement and it was maintained for the entire period of the study ( 7 days).

\section{Enterococcus faecalis}

The antimicrobial activity upon Enterococcus faecalis was not observed at 24 hours or in the following 7 days, neither for the commercial sealers, nor for the experimental material, or its components (Figure 3 ).

There is no information on the possible activity during the first 24 hours because this didn't represent the purpose of our research. 

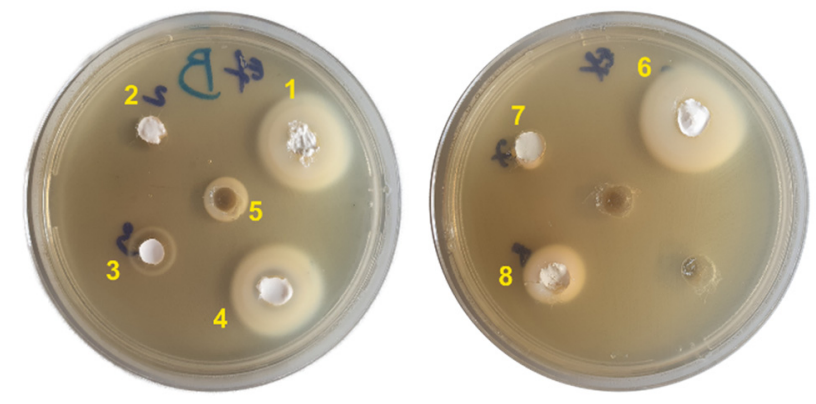

Figure 3. ADT of multiple sealers on Enterococcus faecalis inoculated plate:

1 - Tricalcium silicate $\left(\mathrm{Ca}_{3} \mathrm{SiO}_{5}\right), 2$ - Magnesium silicate $\left(\mathrm{Mg}_{2} \mathrm{SiO}_{4}\right), 3$ - Zirconium dioxide $\left(\mathrm{ZrO}_{2}\right), 4$ - Experimental sealer (EES), 5 - Zinc chloride $\left(\mathrm{ZnCl}_{2}\right)$,

6 - TotalFill BC Sealer, 7 - MTA Bioceramic Sealer, 8 - MTA-Fillapex

Enterococci are a group of opportunistic pathogens found in the gastrointestinal tract [28]. Among these cocci, E. faecalis is of interest because, if present in the microbiota of infected root canals, in most of the cases it is associated with chronic apical periodontitis, especially with cases that are refractory to endodontic treatment $[29,30]$. It is a gram positive facultative anaerobic bacterium that can penetrate deep into dentinal tubules and form biofilms. $E$ faecalis can tolerate increased $\mathrm{pH}$, up to 11.5 , and prolonged starvation. Due to its virulence factors and biofilm formation the microorganism is resistant to many intracanal medicaments, including antibiotics and calcium hydroxide [31,32].

Various studies using the diffusion method on Muller-Hinton agar were performed to assess the antimicrobial properties against $E$. faecalis of available commercial endodontic sealers.

Following a systematic review, AlShwaimi et al [33] concluded that, even though many of the studies investigated reported some form of antibacterial activity against $E$. faecalis, it typically only persisted for up to 24 hours, depending on the analysed endodontic material. The activity was usually lost after the material was set, with no observable inhibition zones from day 2 to 7 [33].

Conventional materials like zinc-oxide-eugenol or epoxy resin-based sealers are known to exhibit strong antibacterial effect against $E$. faecalis [34]. Nonetheless, they are toxic, cytotoxic, or mutagenic for human cells, especially the ones containing formaldehyde [35].

Bioceramic materials are newly introduced on the market, and there isn't enough available data. Our study revealed no antibacterial effect against E. faecalis at 24 hours, for all the tested samples. Similar studies in the literature show conflicting evidence [16]. This may be due to different 
investigation methods, materials or bacterial strains used, duration of the research, concentration of $E$. faecalis, or method of inoculation.

It might also be possible they do not present a pronounced antibacterial effect against $E$. faecalis, thus different results of the studies performed to date. A standardized method would be necessary when investigating this bacterium, as different tests can offer different results.

The fact that the antimicrobial activity upon $E$. faecalis was not noticeable when studies using the ADT method were performed, as opposed to some cases when DCT was used, can lead to the encouraging inference that bioceramic sealers might have some weak inhibitory effect on this class of enterococci. Comparative studies that used ADT and DCT methods revealed the antimicrobial effect in the latter [4].

Antimicrobial activity is a desired property of root canal obturating materials, as they may entomb and neutralize the residual micro-organisms remaining after chemo-mechanical instrumentation. However, materials exhibit such properties on a limited number of species, and for a limited amount of time.

It is known that antibacterial properties of endodontic sealers are at their highest levels immediately after preparation and decreases in time, as the material sets [27]. Consequently, most of the antimicrobial ADT studies were performed on freshly mixed endodontic sealers evaluating their activity shortly after placement, or at different time intervals mostly within the first 24 hours [36]. This would be relevant if the in vivo setting time would be comparable to the sealers producer's statement. However, Allan et al (2001) evaluated the setting time of different endodontic sealers both under benchtop conditions and under simulated clinical conditions. Their study revealed that, in simulated clinical conditions, all investigated materials were only partially set after 1 week, and requested at least 4 weeks for complete setting, considerably longer than the time required for in vitro setting [37].

Following this, while the material is not completely set, in areas where its pasty consistency is maintained, it may be possible for it to still exhibit antimicrobial properties. Taking this into consideration, our study upon the antimicrobial activity was conducted for a period of 7 days.

Bioceramic endodontic sealers are considered the best alternative for obturating root canals due to their superior properties. Regarding their antimicrobial activity, they might not possess such an increased effect compared to other classes of endodontic sealers, but they have the benefit of being the most biocompatible of all, and this should make them the materials of choice. Therefore, it is important not to fully rely on the ability of endodontic materials to neutralize the microorganisms from infected root canals. It is desirable to ensure that $E$. faecalis, and $C$. albicans are eliminated before performing the obturation with bioceramic materials by using other 
means of decontamination: chlorhexidine $2 \%$, chitosan, propolis, MTAD, photon-induced photoacoustic streaming (PIPS), quaternary ammonium silane (k21) [38-42].

\section{CONCLUSIONS}

Analysing the results of the study it was concluded that experimental endodontic sealers' (EES) antimicrobial behaviour upon the tested strains was comparable to similar bioceramic materials available on the market.

Antifungal properties against $C$. albicans were observed for all commercial sealers as well as for tricalcium silicate and the experimental composition (EES), for up to 7 days.

The measurements performed to determine the samples' effects upon $E$. faecalis after the first 24 hours were not encouraging, as no inhibitory activity was detected for any of the materials tested.

More sensitive testing methods might be needed to accurately assess the effectiveness of bioceramic materials against microorganisms. We intend to further evaluate the experimental sealer and using the DCT (direct contact test) method, for a more accurate conclusion regarding its activity in relation to microorganisms.

This line of research should be further pursued, since the new bioceramic material is based on compounds that are nontoxic, biocompatible, and bioactive: tricalcium silicate and magnesium silicate.

\section{EXPERIMENTAL SECTION}

\section{Experimental endodontic sealer (EES)}

The main constituents of the experimental endodontic sealer were tricalcium silicate, magnesium silicate (forsterite), and zirconium oxide.

Nano-sized tricalcium silicate $\mathrm{Ca}_{3} \mathrm{SiO}_{5}$ was obtained using the sol-gel method from $\mathrm{Ca}\left(\mathrm{NO}_{3}\right)_{2} \times 4 \mathrm{H}_{2} \mathrm{O}$-calcium nitrate tetra hydrate (Merck) and TEOS - $\mathrm{C}_{8} \mathrm{H}_{20} \mathrm{O}_{4}$ Si-tetraethyl orthosilicate (Merck), molar ratio $\mathrm{CaO}: \mathrm{SiO}_{2}$ was established at 3:1. As $\mathrm{pH}$ regulators ethanol $\left(\mathrm{C}_{2} \mathrm{H}_{5} \mathrm{OH}\right)$ and nitric acid $\left(\mathrm{HNO}_{3}\right)$ were used [43].

Forsterite nano powder was synthesized by sol gel method using magnesium nitrate hexahydrate $\mathrm{Mg}\left(\mathrm{NO}_{3}\right)_{2} \times 6 \mathrm{H}_{2} \mathrm{O}$ (Merck) and tetraethyl orthosilicate $\mathrm{C}_{8} \mathrm{H}_{20} \mathrm{O}_{4} \mathrm{Si}$ (Merck), in a molar ratio Mg:Si of 2:1. Nitric acid was used as a $\mathrm{pH}$ regulator [44]. 
Both nanomaterials were synthesized and characterised in the laboratory. Their biocompatibility and physical properties were investigated $[43,44]$.

The bioceramic experimental endodontic sealer (EES) was formulated as a two-component powder-liquid material. The solid component consists of $74 \%$ tricalcium silicate $\left(\mathrm{Ca}_{3} \mathrm{SiO}_{5}\right) ; 25 \%$ magnesium silicate $\left(\mathrm{Mg}_{2} \mathrm{SiO}_{4}\right)$, and $1 \%$ zirconium dioxide $\left(\mathrm{ZrO}_{2}\right)$. In order to obtain the pasty consistency required, $2 \%$ Zinc chloride $\left(\mathrm{ZnCl}_{2}\right)$ solution was added as the liquid component.

\section{Antimicrobial properties}

Agar well diffusion test (ADT) was used to determine the antimicrobial properties of the experimental sealer and its individual components and compare them to available commercially endodontic sealers. This is a modified version of the widely used disk diffusion antibiotic susceptibility test, adapted for semisolid substances [45], being the most used method to assess the antimicrobial activity of endodontic sealers [16]. The specific protocol employed in this study was adapted from Gürel et al [18].

Eight samples were tested: tricalcium silicate, magnesium silicate, zirconium dioxide (Merk, Germany), zinc chloride (Merk, Germany), experimental endodontic sealer (EES), TotalFill BC Sealer (FKG, Switzerland), MTA Bioceramic Sealer (Henry-Schein USA), MTA-Fillapex (Angelus, Brazil). The similarity between the tested sealers and the experimental material consists in their composition being based on calcium silicates as major compounds, with or without resins addition. Their composition, as indicated by the producer, is shown in Table 2.

Two microbial strains were used: Enterococcus faecalis ATCC 29212 (American Type Culture Collection), and Candida albicans ATCC 10231. E. faecalis was inoculated on Columbia agar with $5 \%$ sheep blood (Bio-Rad, Marnes la Coquette,France) and incubated aerobically for $24 \mathrm{~h}$ at $37^{\circ} \mathrm{C}$. C. albicans was inoculated on Sabouraud chloramphenicol gentamicin agar (Bio-Rad, Marnes la Coquette,France) for $48 \mathrm{~h}$ at $37^{\circ} \mathrm{C}$.

Suspensions (in $0.9 \%$ saline) with an optical density of $0.5 \mathrm{McF}$ arland $\left(1.5 \times 10^{8} \mathrm{CFU} / \mathrm{mL}\right.$, colony formation units) were prepared from 24 hours colonies of $E$. faecalis and 48 hours colonies of $C$. albicans. The optical density was controlled using a densitometer (DEN-1 McFarland Densitometer, Biosan SIA, Riga, Latvia).

Mueller-Hinton agar plates (Merck KGaA, Darmstadt, Germany) were used for antimicrobial activity testing. Five equally spaced wells with a diameter of $6 \mathrm{~mm}$ and a depth of $3 \mathrm{~mm}$, were punched in each Mueller-Hinton agar plate using a sterile cork borer. 
Table 2. Chemical composition of the tested samples.

\begin{tabular}{|c|c|c|c|}
\hline No & Sample & $\begin{array}{l}\text { Form of } \\
\text { presentation }\end{array}$ & Composition \\
\hline 1 & $\begin{array}{l}\text { Tricalcium silicate } \\
\qquad\left(\mathrm{Ca}_{3} \mathrm{SiO}_{5}\right)\end{array}$ & $\begin{array}{l}\text { Powder-liquid } \\
\text { system }\end{array}$ & $\begin{array}{c}\text { Tricalcium silicate }\left(\mathrm{Ca}_{3} \mathrm{SiO}_{5}\right) \\
\text { Zinc chloride }\left(\mathrm{ZnCl}_{2}\right) 2 \% \text { solution }\end{array}$ \\
\hline 2 & $\begin{array}{l}\text { Magnesium silicate } \\
\quad\left(\mathrm{Mg}_{2} \mathrm{SiO}_{4}\right)\end{array}$ & $\begin{array}{l}\text { Powder-liquid } \\
\text { system }\end{array}$ & $\begin{array}{c}\text { Magnesium silicate }\left(\left(\mathrm{Mg}_{2} \mathrm{SiO}_{4}\right)\right. \\
\text { Zinc chloride }\left(\mathrm{ZnCl}_{2}\right) 2 \% \text { solution }\end{array}$ \\
\hline 3 & $\begin{array}{c}\text { Zirconium dioxide } \\
\left(\mathrm{ZrO}_{2}\right) \text { (Merk, Germany) }\end{array}$ & $\begin{array}{l}\text { Powder-liquid } \\
\text { system }\end{array}$ & $\begin{array}{c}\text { Zirconium dioxide }\left(\mathrm{ZrO}_{2}\right) \\
\text { Zinc chloride }\left(\mathrm{ZnCl}_{2}\right) 2 \% \text { solution }\end{array}$ \\
\hline 4 & $\begin{array}{c}\text { Experimental } \\
\text { endodontic sealer (EES) }\end{array}$ & $\begin{array}{l}\text { Powder-liquid } \\
\text { system }\end{array}$ & $\begin{array}{l}\text { Tricalcium silicate }\left(\mathrm{Ca}_{3} \mathrm{SiO}_{5}\right) \\
\left.\text { Magnesium silicate } \mathrm{Mg}_{2} \mathrm{SiO}_{4}\right) \\
\text { Zirconium dioxide }\left(\mathrm{ZrO}_{2}\right) \\
\text { Zinc chloride }\left(\mathrm{ZnCl}_{2}\right) 2 \% \text { solution }\end{array}$ \\
\hline 5 & $\begin{array}{c}\text { Zinc chloride }\left(\mathrm{ZnCl}_{2}\right) 2 \% \\
\text { solution (Merk, } \\
\text { Germany) }\end{array}$ & $\begin{array}{l}\text { Single } \\
\text { component } \\
\text { liquid }\end{array}$ & Zinc chloride $\left(\mathrm{ZnCl}_{2}\right) 2 \%$ solution \\
\hline 6 & $\begin{array}{l}\text { TotalFill BC Sealer } \\
\text { (FKG, Switzerland) }\end{array}$ & $\begin{array}{l}\text { Single } \\
\text { component } \\
\text { paste }\end{array}$ & $\begin{array}{l}\text { Zirconium oxide } \\
\text { Tricalcium silicate } \\
\text { Dicalcium silicate } \\
\text { Calcium hydroxide }\end{array}$ \\
\hline 7 & $\begin{array}{l}\text { MTA Bioceramic Sealer } \\
\text { (Henry Schein USA) }\end{array}$ & $\begin{array}{l}\text { Two paste } \\
\text { system }\end{array}$ & $\begin{array}{l}\text { Paste A: Salicylate resin, Natural } \\
\text { resin, Calcium tungstate, } \\
\text { Nanoparticulated silica } \\
\text { Paste B: Diluting resin } \\
\text { Mineral trioxide aggregate } \\
\text { Titanium dioxide } \\
\text { Silicon dioxide }\end{array}$ \\
\hline 8 & $\begin{array}{l}\text { MTA-Fillapex } \\
\text { (Angelus, Brazil) }\end{array}$ & $\begin{array}{l}\text { Two paste } \\
\text { system }\end{array}$ & $\begin{array}{l}\text { Paste A: Salicylate resin, Bismuth } \\
\text { trioxide, Fumed silica Paste B: } \\
\text { Mineral trioxide aggregate, Fumed } \\
\text { silica, Titanium dioxide, Base resin }\end{array}$ \\
\hline
\end{tabular}

The Mueller-Hinton plates were inoculated with the prepared suspensions. The wells were then filled with the materials to be tested. The solvent was also used on its own as negative control, being deposited in a dedicated well. 
L. I. TIMIS, M. GOREA, C. COSTACHE, I. A. COLOSI, P. ȘCHIOPU, P. Ș. PANAITESCU,

A. DELEAN, D. I. DUMITRASCU, R. S. CÂMPIAN

The plates were subsequently incubated aerobically at $37^{\circ} \mathrm{C}$ for 7 days. The antimicrobial agent, where present, diffused in the agar medium and inhibited the growth of the tested microbial strain. The diameter of the inhibition zone was measured recorded and compared every $24 \mathrm{~h}$ using an electronic calliper with an accuracy of $\pm 0.2 \mathrm{~mm}$ ).

\section{ACKNOWLEDGMENTS}

This work was supported by PhD Research Project no. PCD 1033/66/January 13, 2021, offered by luliu Hațieganu University of Medicine and Pharmacy, Cluj-Napoca, Romania.

\section{REFERENCES}

1. D.A. Fonseca; A.B. Paula; C.M. Marto; A. Coelho; S. Paulo; J.P. Martinho; E. Carrilho; M.M. Ferreira; Materials (Basel), 2019, 12(24), 4113.

2. E. Carlos; H. Roberto; R.A.E. Cyntia; H.G.A. Ana; D.S. Manoel; D.P. Jesus; Braz. Dent. J., 2014, 25, 25-31.

3. K. Ruksakiet; L. Hanák; N. Farkas; P. Hegyi; W. Sadaeng; L.M. Czumbel; T. Sang-Ngoen; A. Garami; A. Mikó; G. Varga; Z. Lohinai; J. Endod., 2020, 46(8), 1032-1041.

4. C. Poggio; F. Trovati; M. Ceci; M. Colombo; G. Pietrocola; J. Clin. Exp. Dent., 2017, 9(6), e743-e748.

5. Y. Huang; X. Li; P. Mandal; Y. Wu; L. Liu; H. Gui; J. Liu; BMC Oral Health, 2019, 19(1), 118.

6. L. BIZO; K. SABO; R. BARÁBAS; G. KATONA; L. BARBU-TUDORAN; A. BERAR; Studia UBB Chemia, 2020, LXV(1), 137-148.

7. D.G. Olaru; A. Olaru; G.H. Kassem; M.V. Popescu-Drigă; L.R. Pinoşanu; D.I. Dumitrascu; E.L Popescu; D.M. Hermann; A. Popa-Wagner; Rom. J. Morphol. Embryol., 2019, 60(3), 787-792.

8. S. Jitaru; I. Hodisan; L. Timis; A. Lucian; M. Bud; Clujul Med., 2016, 89(4), 470473.

9. D.G. Seo; D. Lee; Y.M. Kim; D. Song; S.Y. Kim; Materials (Basel), 2019, 12(15), 2482.

10. P.J. Penha da Silva; M.F. Marceliano-Alves; J.C. Provenzano; R.L.A. Dellazari; L.S. Gonçalves; F.R.F. Alves; Eur. J. Dent., 2021, 15(3), 475-480.

11. M.A. Elsayed; E.E. Hassanien; A.A.E. Elgendy; Eur. Endod. J., 2021, 6(2), 183188.

12. G. Sfeir; C. Zogheib; S. Patel; T. Giraud; V. Nagendrababu; F. Bukiet; Materials (Basel), 2021, 14(14), 3965. 
13. L.B. Mestieri; A.L. Gomes-Cornélio; E.M. Rodrigues; L.P. Salles; R. BossoMartelo; J.M. Guerreiro-Tanomaru; M. Tanomaru-Filho; J. Appl. Oral. Sci., 2015, 23(5), 467-471.

14. P. Mangat; A. Dhingra; S. Muni; H.K. Bhullar; J. Conserv. Dent., 2020, 23(6), 571-576.

15. G. Singh; I. Gupta; F.M.M. Elshamy; N. Boreak; H.E. Homeida; Eur. J. Dent., 2016, 10(3), 366-369.

16. M. Šimundić Munitić; T. Poklepović Peričić; A. Utrobičić; I. Bago; L. Puljak; PLoS One, 2019, 14(10), e0223575.

17. L.W. Lee; Y.L. Lee; S.H. Hsiao; H.P. Lin; J. Formos. Med. Assoc., 2017, 116(6):448-456.

18. M. Gürel; E.Ö. Demiryürek; T. Özyürek; T. Gülhan; Int. J. Appl. Dent. Sci., 2016; 2(3), 19-22.

19. T.M.T. Waltimo; E.K. Sirén; H.L.K. Torkko; I. Olsen; M.P.P. Haapasalo; Int. Endod. J., 1997, 30(2), 96-101.

20. D. Montelongo-Jauregui; J.L. Lopez-Ribot; J. Fungi (Basel), 2018, 4(4), 122.

21. T. Young; O.A. Alshanta; R. Kean; D. Bradshaw; J. Pratten; C. Williams; C. Woodall; G. Ramage; J.L. Brown; Microorganisms, 2021, 9(1), 59.

22. A. Alberti; S. Corbella; S. Taschieri; L. Francetti; K.S. Fakhruddin; L.P. Samaranayake; PLoS One, 2021;16(7), e0255003.

23. O.A. Alshanta; S. Shaban; C.J. Nile; W. McLean; G. Ramage; Antibiotics (Basel), 2019, 8(4), 204.

24. J.F. Jr Siqueira; B.H. Sen; Oral Surg. Oral Med. Oral Patho.I Oral Radiol. Endod. 2004, 97(5), 632-641.

25. Y.J. Yoo; A.R. Kim; H. Perinpanayagam; S.H. Han; K.Y. Kum; Microorganisms, 2020, 8(9), 1300.

26. F. Jafari; S. Jafari; H. Samadi Kafil; T. Momeni; H. Jamloo; Iran. Endod. J., 2017, 12(1), 98-102.

27. R.K. Rathod; P.D Taide; R.D. Dudhale; Niger. J Surg., 2020, 26(2), 104-109.

28. D. Djorić; N.E. Minton; C.J. Kristich; Mol. Oral. Microbiol., 2021, 36(2), 132-144.

29. C. Tennert; M. Fuhrmann; A. Wittmer; L. Karygianni; M.J. Altenburger; K. Pelz;

E. Hellwig; A. Al-Ahmad; J. Endod, 2014, 40(5), 670-677.

30. R. Vidana; A. Sullivan; H. Billström; M. Ahlquist; B.Lund; Letters in Applied Microbiology, 2011, 109-115.

31. P.H. Ferrari; S. Cai; A.C. Bombana; Int. Endod. J., 2005, 38(6), 372-380.

32. P.N Nair; Int. Endod. J., 2006, 39(4), 249-281.

33. E. AlShwaimi; D. Bogari; R. Ajaj; S. Al-Shahrani; K. Almas; A. Majeed; J. Endod., 2016, 42(11), 1588-1597.

34. I.M. Saleh; I.E. Ruyter; M. Haapasalo; D. Ørstavik; Int. Endod. J., 2004, 37(3), 193-198.

35. A. Kaur; N. Shah; A. Logani; N. Mishra; J. Conserv. Dent., 2015, 18(2), 83-88.

36. M. Šimundić Munitić; A. Budimir; S. Jakovljević; I. Anić; I. Bago; Acta Stomatol. Croat., 2020, 54(1), 3-9.

37. N.A. Allan; R.C. Walton; M.A. Schaeffer; J. Endod., 2001, 27(6), 421-423. 
L. I. TIMIS, M. GOREA, C. COSTACHE, I. A. COLOSI, P. ȘCHIOPU, P. Ș. PANAITESCU,

A. DELEAN, D. I. DUMITRASCU, R. S. CÂMPIAN

38. N. Ballal; M. Kundabala; K. Bhat K; S. Acharya; M. Ballal; R. Kumar; P. Prakash; Aust. Endod. J., 2009, 35(1), 29-33.

39. S. Arslan; H. Ozbilge; E.G. Kaya; O. Er; Saudi Med. J., 2011, 32(5), 479-83.

40. B.M. Newberry; S. Shabahang; N. Johnson; R. M. Aprecio; M. Torabinejad; J. Endod. 2007, 33(11), 1352-1354.

41. N. Mandras; D. Pasqualini; J. Roana; V. Tullio; G. Banche; E. Gianello; F. Bonino; A.M. Cuffini; E. Berutti; M. Alovisi; J. Clin. Med., 2020, 9(12), 3915.

42. E.S.K. Kok; X.J. Lim; S.X. Chew; S.F. Ong; L.Y. See; S.H. Lim; L.A. Wong; F. Davamani; V. Nagendrababu; A. Fawzy; U. Daood; BMC Oral Health, 2021, 21(1), 116.

43. L. Timiş; A. Avram; M. Gorea; L. Bizo; S. Cîmpean; R. Câmpian; Studia UBB Chemia, 2020, 65, 157-169.

44. M. Gorea; M.A. Naghiu; A. Avram; I. Petean; M. Tomoaia-Cotisel; Studia UBB Chemia, 2019, 64, 383-392.

45. M. Balouiri; M. Sadiki; S.K. Ibnsouda; J. Pharm. Anal., 2016, 6(2), 71-79. 